\title{
REPRODUCTIVE PERFORMANCEAND EGG QUALITY TRAITS OF CROSSBREEDING BETWEEN TWO STRAINS OF SNAILS
}

\author{
CARACTERÍSTICAS REPRODUCTIVAS Y CALIDAD DEL HUEVO DEL CRUZAMIENTO \\ ENTRE DOS LÍNEAS DE CARACOLES
}

\author{
Okon, B. ${ }^{1}$, Ibom, L.A. ${ }^{2}$ and Odido, E.E. ${ }^{1}$ \\ 1Dept. Animal Science. University of Calabar. Calabar. Nigeria. blessedbassey4destiny@yahoo.com \\ ${ }^{2}$ Dept. Animal Science. Cross River University of Technology. Obubra Campus. Cross River State. Nigeria.

\section{AdDitiOnAl KEYWORDS} \\ Heliciculture. Archachatina marginata saturalis.

\section{PaLABRAS CLAVE ADICIONALES} \\ Helicicultura. Archachatina marginata saturalis.
}

\section{SUMMARY}

Forty five snails (Archachatina marginata saturalis ) of each strain (black and white skinned) were distributed into three groups on the basis of body weight: I: $40-44 \mathrm{~g}$; II: $45-49 \mathrm{~g}$ and III: $50-54 \mathrm{~g}$. Ten black skinned snails from each group were randomly selected and were individually mated with other ten white skinned snails from each group for twelve weeks. Crossing between the two types of snails is possible and its reproductive parameters are similar to those of pure lines. The body weight did not affect any of reproductive parameters evaluated.

\section{RESUMEN}

Se emplearon caracoles Archachatina marginata saturalis de dos líneas: piel negra y piel blanca. A partir de 45 caracoles de cada tipo distribuidos en tres grupos según su peso vivo: I: 40-44 g; II: $45-49$ g y III: 50-54 g, fueron seleccionados aleatoriamente 10 caracoles de carne negra de cada grupo y fueron cruzados individualmente durante 12 semanas con otros 10 caracoles de carne blanca de cada grupo. El cruce entre ambos tipos de caracoles es posible y sus parámetros reproductivos son similares a los de líneas puras. El peso vivo no afectó a ninguno de los parámetros reproductivos evaluados.

\section{INTRODUCTION}

Animal protein has continued to diminish from year to year in the diet of average Nigerians. This can be attributed in part to the economic down-turn and the poverty level of Nigerians which have made it almost impossible for the common man to buy products of conventional sources of animal protein.

ILCA (1993) reported that Nigerians only consumed $6.8 \mathrm{~g}$ of animal protein per person per day as against $8.3 \mathrm{~g}, 11.6 \mathrm{~g}, 12.7 \mathrm{~g}, 38.1$ $\mathrm{g}$ and $70 \mathrm{~g}$ for Cameroon, Ghana, Niger, Somalia and North America respectively. There is need to promote the production of non-conventional meat sources to complement the conventional animals as sources of animal protein supply and therefore bridge the gap in animal protein intake deficit. Ebenebe (2000) advocated the integration into our farming system such non-conventional meat source as snail species which Nigeria is richly endowed with. Adesope (2000) also stated that snail is one of the micro-livestock that has recently attracted attention among agriculturists and farmers in Nigeria as an aftermath of alarm raised by Food and Agriculture Organization on animal protein deficiency among Nigerians.

According to Ejidike (2002), land snails gathered from the forest have traditionally been a major ingredient in the diet of West Africans living in the humid tropical zone. These land snails, especially African giant snail Archachatina marginata, had been 
classified on the basis of foot colour into back and white by Amusan and Omidiji (1998), Akinnusi (2004) and Omole et al. (2007). Snails are hermaphrodites, having high rate of productivity, although snails must fertilize each other simultaneously before they lay eggs (Amusan and Omidiji 1998, Payne and Wilson, 1999 and Akinnusi, 2004). Akinnusi (2004) further stated that snails are very choosy in their mating partners. Besides, Omole and Kehinde (2005) observed that snails are sometimes uninterested in mating with other snails of the same species. It is possible that the black skinned and white skinned strains may not mate because of the differences in their genetic composition. The non-mating of these strains had been widely speculated in many quarters, even among researchers (Amubode, 1994 and Akinnusi, 2004). There is no documented data or evidence to show whether or not these two strains can mate. Therefore the aim of this study was to assess the possibility of crossbreeding between the black skinned and white skinned $A$. marginata. Their reproductive performance and some egg quality parameters were also assessed.

\section{MATERIALSAND METHODS}

The experiment was conducted at the Botanical garden, University of Calabar, Calabar. The area provided a microenvironment similar to the natural habitat of snails as it is planted with trees (citrus, mango, almond, pawpaw, plantain and banana) and crops (cassava, yam, cocoyam and maize). These trees and crops provided shade that protected the hutches from direct sunlight and heavy rainfall.

Ninety breeder snails, forty-five each of the black skinned and white skinned strains with a weight range of 40-54 g purchased from Watt market of Calabar were used for the experiment. They were allowed acclimatization period of four weeks during which time they would have shed their eggs. The average temperature, relative humidity and photoperiod during the experimental period (June to September, 2008) ranged from $25^{\circ} \mathrm{C}$ to $30^{\circ} \mathrm{C}, 50 \%$ to $70 \%$ and 12 to $18 \mathrm{~h}$ respectively.

Each strain was grouped on the basis of body weight range in 3 groups of 15 animals: 40-44 g, group I; 45-49 g group II and 50-54 $\mathrm{g}$, group III. They were marked with green pen and managed individually in $15 \times 15 \times 30$ $\mathrm{cm}$ hutches. Ten black skinned snails from each group were randomly selected and were individually crossbreeding with others ten white skinned snails from each group, leaving them together for one week and separating them for another one week.

The snails were fed pawpaw leaves supplemented with formulated diet. The feed and water were given ad libitum throughout the experimental period (twelve weeks). The diet was formulated to contain $23.04 \% \mathrm{CP}$ and $2995 \mathrm{kcal} / \mathrm{kgME}$ with the following ingredients; maize $57.60 \%$, soyabean meal $38.40 \%$, bone meal $3.0 \%$ and vit./min. premix $1.0 \%$.

Parameters evaluated during the study included clutch size, mean egg weight $(\mathrm{g})$, length $(\mathrm{mm})$ and width $(\mathrm{mm})$, incubation period (days), percent hatchability of eggs and hatchlings weight. Data collected were subjected to analysis of variance (ANOVA) and means separated using least significant difference (LSD) as outlined by Steel and Torrie(1980).

\section{RESULTSANDDISCUSSION}

Results of evaluated parameters are showed in table I. There was no significant difference $(p>0.05)$ in clutch size among the three age groups of body weight. The mean clutch sizes obtained in this study were $6.50 \pm 0.57$ (group I), $6.00 \pm 0.38$ (group II) and $5.75 \pm 0.60$ (group III). These values are higher than the mean value of 5.23 reported by Ibom et al. (2008) for white skinned ectotype, but lower than the value of 7.8 reported by the same authors for black skinned ectotype. However, these results are lower than the values of 7,8 and 8.5 
reported by Awesu (1980), Reid (1989) and Amubode (1994) respectively.

The mean incubation periods were respectively $27.00 \pm 1.41$ days, $25.86 \pm 1.48$ days and $26.86 \pm 0.98$ days for groups I, II and III, although were not statistically different $(p>0.05)$. Shorter incubation periods were observed when temperature was high, while low temperature increased incubation periods. The incubation periods obtained are higher than the values of 14-21 days and 23.0 days reported by Amubode (1994). These values however fall within the range of 24-37 days, 25-30 days and 25-32 days reported by Ogogo (1989), Amusan and Omidiji (1998) and Omole and Kehinde(2005).

The mean percent hatchability were $60.60 \pm 8.26$ (group I), $61.77 \pm 8.34$ (group II) and $60.01 \pm 7.78$ (group III), although there were no significant differences between the body weights groups. The results showed that the clutch with short incubation period (group II) could had a higher percent hatchability $(61.77 \%)$. The percent hatchability values are close to the values of $66.9 \%$, $68.4 \%$ and $70 \%$ reported by Awesu (1980), Ogogo(1989)and Akinnusi(2004), respectively.

Expectedly, the hatchlings weight increased from first to six th week, although there were no significant difference $(p>0.05)$ among body weight groups. The results at first week are lower than those reported by
Amubode (1994) and Akinnusi (1998), and the results at sixth week are also lower than the findings of Akinnusi (1998). The nonsignificant differences may indicate that the hatchlings have similar genetic composition.

The mean egg weights were no significantly different among groups, and were $1.06 \pm 0.03 \mathrm{~g}$ in group I, $1.05 \pm 0.04 \mathrm{~g}$ in group II and $1.04 \pm 0.04 \mathrm{~g}$ in group III. The mean egg weights recorded were lower than the $3.0 \mathrm{~g}$ and $1.80 \mathrm{~g}$ reported by Amubode (1994) and Ibomet al. (2008) for black skinned ectotype.

The mean egg lengths obtained were $12.37 \pm 0.51 \mathrm{~mm}$ (group I), $12.35 \pm 0.59 \mathrm{~mm}$ (group II) and $12.08 \pm 0.46 \mathrm{~mm}$ (group III) and confirming that egg length does not change with body weight. These results are higher than the mean values of $1.61 \mathrm{~mm}$ and $1.43 \mathrm{~mm}$ reported by Ibom et al. (2008) for black skinned and white skinned ectotypes of snails respectively. However, are lower than the mean values of $16.0 \mathrm{~mm}$ and $19.7 \mathrm{~mm}$ reported by Awesu (1980) and Amubode (1994) respectively for black skinned snails.

The mean egg width obtained were $10.29 \pm 0.17 \mathrm{~mm}, 10.30 \pm 0.16 \mathrm{~mm}$ and $10.36 \pm 0.15$ $\mathrm{mm}$ for groups I, II and III respectively, although there was no significant difference. These results are lower than the mean value of $15.7 \mathrm{~mm}$ reported by Plummer (1975) and Amubode (1994), but higher than the 1.29 $\mathrm{mm}$ and $1.05 \mathrm{~mm}$ reported by Ibom et al.

Table I. Reproductive and egg quality parameters (mean \pm standard error) of the mating between black $x$ white skinned snails (Archachatina marginata). (Parámetros reproductivos y de calidad del huevo (media \pm error estándar) del cruzamiento entre caracoles de carne blanca y negra (Archachatina marginata)).

\begin{tabular}{lcccc}
\hline Variable & Group I & Group II & Group III & p value \\
\hline Clutch size & $6.00 \pm 0.38$ & $5.75 \pm 0.60$ & $6.50 \pm 0.57$ & $>0.05$ \\
Incubation period (days) & $27.00 \pm 1.41$ & $25.86 \pm 1.48$ & $26.86 \pm 0.98$ & $>0.05$ \\
Percent hatchability & $60.60 \pm 8.26$ & $61.77 \pm 8.34$ & $60.01 \pm 7.78$ & $>0.05$ \\
Hatchling weight at first week (g) & $1.03 \pm 0.13$ & $1.02 \pm 0.23$ & $1.01 \pm 0.20$ & $>0.05$ \\
Hatchling weight (g) (at 6 weeks) & $2.74 \pm 0.10$ & $2.83 \pm 0.15$ & $2.83 \pm 0.16$ & $>0.05$ \\
Egg weight $(\mathrm{g})$ & $1.06 \pm 0.03$ & $1.05 \pm 0.04$ & $1.04 \pm 0.04$ & $>0.05$ \\
Egg length $(\mathrm{mm})$ & $12.37 \pm 0.51$ & $12.35 \pm 0.59$ & $12.08 \pm 0.46$ & $>0.05$ \\
Egg width $(\mathrm{mm})$ & $10.29 \pm 0.17$ & $10.30 \pm 0.16$ & $10.36 \pm 0.15$ & $>0.05$ \\
\hline
\end{tabular}




\section{OKON, IBOM AND ODIDO}

(2008) for black and white skinned snails respectively. This results confirms that egg width does not change with body weight.

\section{CONCLUSIONS}

This study provides evidence that the

\section{REFERENCES}

Adesope, M.O. 2000. Attitudes of household in a Niger Delta Zone towards snail meat consumption. In: Ukachukwu, S.N. et al. (Eds.). Animal production in the new millennium: challenges and options. NSAP Secretariat. Zaria.

Akinnusi, O. 1998. Life History Studies of Archachatina (Calachatina) marginata (Swainson). Proc. Silver Jubilee Ann. Conf., Nig. Soc. for Anim. Prod. (NSAP). March 21-26, 1998. Abeokuta. Nigeria. pp. 403-404.

Akinnusi, O. 2004. Introduction to snails and snai farming. Triolas Exquisite Venture. Abeokuta. Nigeria.

Amubode, F.O. 1994. Growth and reproductive performance of two species of African giant snail (Achatina achatina and Archachatina marginata). J. Trop. For. Res., 9-10: 68-74.

Amusan, J.A. and Omidiji, M.O. 1998. Edible land snail. A technical guide to snail farming in the tropics. Variety Printers Limited. Ibadan.

Awesu, M.O. 1980. Observations on the biology and management of the West African giant snail (Archachatina marginata). M. Phil. Thesis. University of Ibadan. Ibadan. Nigeria. (Unpublished).

Ebenebe, C.I. 2000. Mini livestock production in Nigeria. The present and future. Proc. $5^{\text {th }}$ Ann. Conf., Anim. Sci. Ass. of Nig. (ASAN). Sept. 1922, 2000. Port Harcourt. Nigeria.

Ejidike, B.N. 2002. Snail rearing practices in Southern Nigeria. Proc. $27^{\text {th }}$ Ann. Conf., Nig. Soc. for Anim. Prod. (NSAP). March 17-21, 2002. Akure. Nigeria. pp. 307-308.

Ibom, L.A., Okon, B. and Essien, A. 2008. Morphometric analysis of eggs laid by two crossbreeding between black skinned and white skinned snails is possible, and shows that the reproductive performance and egg quality parameters are not significantly different between snails body weight ranges.

ectotypes of Archachatina marginata (Swainson) raised in captivity. Proc. $33^{\text {rd }}$ Ann. Conf., Nig Soc. for Anim. Prod. (NSAP). March 16-20, 2008. Olabisi Onabanjo University. Ago-Iwoye. Ogun State. Nigeria. pp. 28-30.

ILCA. 1993. Handbook of African livestock statistics. ILCA. Addis Ababa. pp. 66.

Ogogo, A.U. 1989. The replacement of cassava flour with groundnut cake in the nutrition of the African snail (Archachatina marginata) (Swainson). M. Sc.Thesis. Department of Wildlife and Fisheries. University of Ibadan. Ibadan. (Unpublished).

Omole, A.J. and Kehinde, A.S. 2005. Backyard snail farming at a glance. Back to Agricultural Series (1). Technovisor Agricultural Publications. Ibadan.

Omole, A.J., Taiwo, A.A. and Amusan, J.A. 2007. Technical guide/bulletin. Practical snail farming. Institute of Agricultural Research and Training, Moor Plantation. Ibadan. Nigeria.

Payne, W.J.A. and Wilson, R.T. 1999. An introduction to animal husbandry in the tropics. $5^{\text {th }}$ ed. Blackwell Publishing Company. Osney Mead. UK. pp. 702-704.

Plummer, J.M. 1975. Observations on the reproduction, growth and longevity of a laboratory colony of Archachatina (Calachatina) marginata. Proc. of the Malacological Society London. 141: 395-413.

Reid, J.C. 1989. A proposal for heliciculture in the Cross River National Park. Mimeo 21.

Steel, R.G.D. and Torrie, J.H. 1980. Principles and procedures of statistics. A biometrical approach, $2^{\text {nd }}$ Ed. McGraw Hill Books. New York.

Archivos de zootecnia vol. 60, núm. 229, p. 156. 